\title{
Intercultural Communication and Mutualistic Relationship between the Chinese and the Minangnese in Padang, West Sumatra, Indonesia
}

\author{
RINIWATY MAKMUR \\ ENGKUS KUSWARNO \\ EVI NOVIANTI \\ NURYAH ASRI SJAFIRAH \\ University of Padjadjaran, Bandung
}

\begin{abstract}
Ethnic-Chinese groups have lived in urban areas throughout Indonesia for hundreds of years, including the city of Padang in West Sumatra. Here, the Chinese have been able to maintain a harmonious relationship with the Minangnese, the original inhabitants of the region and the dominant culture. Though both ethnic groups have a strong trading ethos and profess different religions, a situation that, in theory, encourages social conflict, this is not the case in Padang. However, recent research has sparked concern about growing anti-Chinese sentiments in Indonesia. These findings suggest that the phenomenon of the harmonious relationship between the Chinese and Minangnese in Padang merits further research. This study has been designed to analyze intercultural communication and relations between the Chinese and Minangnese ethnic groups in Padang by utilizing five elements of culture from Samovar, Porter, and McDaniel. It uses a qualitative approach and a case-study method conducted intermittently from January 2016 to June 2017. Data was collected through interviews with 39 ethnic Chinese and Minangnese informants, observations conducted in the predominately Chinese district of Padang (Chinatown), along with document reviews as secondary data. The study found that six out of eight identified characteristics of cultural elements of the Chinese and Minangnese in Padang exhibit significant similarity. These are: history in Padang, collective social organization, values based upon a trading ethos, a situational nature and flexibility to adapt, and the language in common use. The significant similarities of cultural elements leads to effective communication and supports more harmonious inter-ethnic relationships.
\end{abstract}

Keywords: Intercultural communication, mutualistic relationship, chinese and minangnese ethnic groups, cultural elements, effective communication.

\section{INTRODUCTION}

Padang, the capital of West Sumatra province, is also the largest city in terms of size and population on the west coast of Sumatra, Indonesia. Most of the population are of Minangkabau ethnicity, known as the Minangnese, of which the majority are Muslim. There are also people from other ethnicities, such as Javanese, Bataknese, and Chinese (BPS/Statistical Bureau of Padang, 2011). Most of the ethnic Chinese in Padang have routine interactions with the Minangnese and are able to speak the Minang Pondok language, which is the Minangkabau language (Minang) with many terms and pronunciations derived from Chinese dialects. As of the most recent census (2011), there are 9,498 ethnic Chinese in Padang, accounting for $1.1 \%$ of the 833,562 total population (BPS/Statistical Bureau of Padang, 2011).

Ethnic-Chinese groups have lived in Indonesia, including in Padang, for hundreds of years, but with various problems regarding their acceptance as Indonesians. According to Dahana (2015), this was primarily due to the segregation policy of the Dutch colonial 
administration being adopted by the Government of Indonesia. Hoon (2006), in his dissertation on Chinese ethnicity in Indonesia in the post-Suharto era, concluded that the ethnic-Chinese people living in Indonesia continued to be regarded as "outsiders" as they were never accepted as Indonesians. Violence against Chinese ethnic groups in Indonesia has occurred on numerous occasions throughout history, the most recent being in 1998.

Suryadinata (2018) stated that since the start of the Reformation Era, prejudice against the ethnic Chinese, although diminished, continues. Another study (Setijadi, 2017), reported fresh concern about growing anti-Chinese sentiments in Indonesia. Some examples include cases of blasphemy against the former Jakarta Governor Basuki "Ahok" Tjahaja Purnama, an ethnic-Chinese Indonesian (Kompas.com, 2017). In the 2014 and 2019 presidential elections, a disinformation campaign falsely accused one of the presidential candidates of Chinese descent (Matamatapolitik.com, 2018). In July 2016, a complaint from an ethnic-Chinese woman about the loud volume of a local mosque call to prayer in the town of Tanjung Balai in North Sumatra led to riots, looting, attacks, and the burning of several Buddhist and Chinese temples by an angry mob of hundreds (Setijadi, 2017). The woman was subsequently convicted of blasphemy and imprisoned. Setijadi asserts that maintaining inter-ethnic/inter-religious harmony between the Chinese and pribumi (indigenous inhabitants) in Indonesia requires continuous hard work (Setijadi, 2017).

In Padang, Purwanto, (as cited in Erniwati, 2007), noted that the existence of a Chinese community regarded as traders would directly affect the Minangnese, who are similarly labeled. In theory, the socio-cultural background of the Minangnese, which is heavily influenced by Islam, should encourage opposition to and conflict with the Chinese community. However, research on the relationship between the ethnic-Chinese and Minangnese in Padang, conducted by Alfirdaus, Hiariej, and Adeney-Risakotta $(2014,2016)$, found that the relationship between the Chinese and Minangnese in Padang is largely devoid of conflict. Thus, the phenomenon of such a relationship between the Chinese and Minangnese in Padang merits further study in order to understand factors contributing to the relative success of their intercultural communication. The study provides a model for other cities and regions in Indonesia to practice intercultural communication, contributing to efforts to promote multiculturalism in Indonesia. As emphasized by Suparlan (2014), building a multicultural Indonesia is only possible if the importance of multiculturalism is communicated to and understood by the Indonesian people. In addition, there should also be a desire to adopt multiculturalism as a social framework on the local and national level. Multiculturalism is an ideology that recognizes and accepts individual and cultural differences (Suparlan, 2014).

This study observed the phenomenon from an intercultural communication approach. The researchers found no previous studies on intercultural communication between the Chinese and Minangnese ethnic groups in Padang, so this study may be the first. The researchers assume that, in addition to the differences between the ethnic groups, there are also cultural similarities which suggest a preference for collaboration over conflict. One study (Erniwati, 2016) found that the similar Chinese and Minangnese trading ethos supports an environment conducive to peaceful co-existence. With this in mind, this study explored the cultural elements of the two ethnic groups that might explain the factors supporting the nature of communication and relations between both ethnic groups which encourage a low-conflict situation. 


\section{LITERATURE REVIEW}

Culture is a form or pattern of life (Samovar, Porter \& Jain, 1981). People learn to think, feel, believe, and strive for things that fit their culture. What people do, how they act, and how they live and communicate is a response to their culture. Edward T. Hall (as cited in Liliweri, 2016) said that culture is a way of life for a population: the totality of learned behavior patterns, attitudes, and material things. Hall also stated that culture is communication. In this context, Hall said that most of what we know, we learn through communication.

Culture and communication are inseparable because all communication behavior depends on the cultural background (Samovar, Porter \& Jain, 1981). There is thus a mutualistic relationship between culture and communication (Martin and Nakayama, 2010). Communication involves expectation, perception, choice, action, and interpretation (Mulyana, 2012). Every time we communicate with an individual, we recognize that they are immersed in a cultural environment. Thus, what they say and the way they behave is influenced by their culture (Mulyana, 2012). There is the same pattern or similarity in the attitudes and behaviors of people with the same culture. Communication between people from different cultures, such as the Chinese and Minangnese in Padang, is a form of intercultural communication. Therefore, in analyzing communication and relations between the Chinese and Minangnese, the intercultural communication approach is employed.

Samovar, Porter and McDaniel (2010) stated that intercultural communication occurs when members of a particular culture send messages to members of other cultures. Intercultural communication involves people from different cultures, and this makes difference a normative condition. Public reaction and the ability to overcome these differences is the key to a successful intercultural interaction (Samovar, Porter \& Jain, 2008). Gudykunst, Lee, Carmen, Nishida and Ogawa (2005) noted that intercultural communication involves negotiating between cultural codes through communal conversation, that is, the process of communication through which individuals negotiate how they will "live together". In other words, intercultural communication requires willingness to "go along to get along" (Griffin, Ledbetter \& Sparks, 2019).

The difference in communication styles influenced by culture is recognized as one major cause for misunderstanding in intercultural communication (Qin, 2014). Thus, Collier (as cited in Samovar, Porter \& McDaniel, 2010) emphasized that a person's recognized cultural identity and communication style must match the identity and style displayed to him by his interlocutor in order to communicate effectively in intercultural situations. However, due to the possible differences in communication styles, each communicator must find a middle ground, and this search requires flexibility and adaptation. In most cases, the process of adaptation will be made by minority groups - in this case the Chinese population of Padang. The existence of the Minang Pondok language is an example of the ethnicChinese effort to adjust to the local way of life.

While culture is composed of many elements, Samovar, Porter and McDaniel (2010) emphasize five: history, religion, values, social organization, and language. History deals with the origin of a culture; a narrative of events important to members of the society that identifies cultural achievements worthy of pride. Religion, in this case, means a dominant and organized religion with set beliefs and established ceremonies, rituals, taboos, and celebrations. Values are codes of conduct. According to Mulyana (2015), values are normative, and sourced from philosophical issues. For this reason, they are stable and resistant to change. Social organizations usually refer to social systems which establish 
communication networks and regulate personal, family, and social norms. Language is a tool for communication. The five elements are interrelated, although they can be discussed separately. This study used these five elements as guidelines to explore the cultural elements of the Chinese and Minangnese ethnic groups in Padang.

\section{METHODOLOGY}

This research is part of a large qualitative study with a case study conducted intermittently from January 2016 to June 2017. Qualitative method was used as the research objective to understand and describe human behavior involved in intercultural communication. The study attempted to capture the informant's own rationales for their quotidian behavior in specific contexts (Martin \& Nakayama, 2010). The research location was limited to the predominately ethnic-Chinese area in Padang known as Kampung Pondok. Data gathering was conducted from primary and secondary data sources through interview, observation, and document reviews (Sugiyono, 2015).

Purposive and snowball sampling procedures were applied to identify 39 informants for interviewing, consisting of 26 Chinese and 13 Minangnese members of their respective ethnic groups. The researchers used pseudonyms to protect the identity of the informants. Observations were conducted at relevant locations in the survey area, which includes a marketplace, coffee shops, and Chinese ethnic association offices. Reviews of documents, including informants' personal documents, news reports from online and traditional outlets, and other related written data were conducted to supply additional information. Data analysis complied with the qualitative analysis concept: searching for patterns, determining relative importance of knowledge acquired, and deciding what should be communicated. (Moleong, 2015).

\section{RESULTS AND DISCUSSION}

The study shows that there are many similarities between the Chinese and Minangnese populations of Padang based on the five elements of their culture: history, social organization, religion, values, and language.

\section{History}

Neither the Chinese nor the Minangnese are native to Padang. The Minangnese are actually migrants from the Sumatra highlands. The Minangnese are renowned in the region for their tradition of rantau, economic migration, and indeed, Padang was considered to be a rantau destination. Now, however, due to being the dominant ethnic group, Minangnese in general are called "Padang" in popular usage. Elfira (2011) noted that every Minangnese could claim to be from Padang, but not every Padang person can claim to be Minangnese.

The Chinese first migrated to Padang in the 15th century, following the development of Malacca as a trade center (Erniwati, 2007). The Dutch "devide et impera" policy of segregation restricted the activities of the Chinese, driving them into the world of commerce. The Chinese community center in Padang is located in the Kampung Pondok area, often referred to as "Chinatown". Kampung Pondok has been a predominantly Chinese settlement since colonial times (Erniwati, 2007). The Dutch colonial administration required ethnic Chinese to live in Kampung Pondok in order to separate them from the local population. Over the years, Kampung Pondok became the focus the ethnic Chinese community. The pagoda, funeral home, and ethnic Chinese association buildings (called 
Kongsi/Gongsi in Mandarin), and even the cemetery (before being relocated in 2000), were all in the same neighborhood.

Meanwhile, the Minangnese, which is the majority ethnic group, are evenly dispersed throughout the Padang urban area, including the Tanah Kongsi market in Kampung Pondok. Nestled among a row of small houses occupied by the Chinese in Tanah Kongsi market lives a Muslim Minangnese family which has resided there for three generations. The majority of Minangnese profess Islam, so masjid, or mosques, are ubiquitous, including in Tanah Kongsi.

While historical evidence indicates that the two ethnic groups are both migrants to Padang, the Minangnese have a stronger geographical- and cultural-proximity relationship to the city as compared to the Chinese. In addition, the Minangnese population is much larger. This gives the Minangnese a decisive position in the inter-ethnic relationships in Padang. Elfira notes:

\footnotetext{
"As a dominant ethnic group in Padang, with increasing dominance demographically, economically, and politically, the Minangnese contribute significantly to the nature of inter-ethnic relationships in Padang" (Elfira, 2011).
}

The history of favorable inter-ethnic relations between the Chinese and Minangnese is acknowledged by both ethnic groups as a cultural achievement of community pride. The Minangnese themselves, on various occasions, emphasize a principle which mandates members to "live intelligently and die as believers". This principle teaches the Minangnese to try to live a balanced life, and they believe that this affects their relationship with nonMinang fellows. Erniwati (2016) stated that philosophies held by Minangnese to live in harmony with others, put the common interest first, and avoid conflict, are determinant factors in the harmonious inter-ethnic relationship in Padang. Meanwhile, the Chinese obey the Confucian edicts that encourage harmonious social relationships (Samovar, Porter \& McDaniel, 2010). A recent study of Confucian values and communication noted that Confucianism dominated the Chinese political ideology and provided archetypal images for Chinese communication behavior for over two thousand years (Joyce, Norhafezah \& Mohd Khairie, 2014).

Despite a history of hundreds of years in Padang, as a minority ethnic group, the Chinese try to be flexible and adapt to developments in the social, economic, and political environment. As explained by one of the informants (Tj), "We adapt to the developing conditions." Adjustment, or adaptation, is recognized by the Chinese community in Padang as an important factor in blending into the society and maintaining a harmonious relationship with the Minangnese. One of the tangible proofs of their adaptation is the adoption of the Minang Pondok creole language, a mixture of the Minang language and the Hokkien Chinese dialect spoken by most historical migrants. Almost all residents of Kampung Pondok use Minang Pondok in daily life, as most ethnic Chinese there can no longer speak Chinese. 


\section{Social Organization}

Matrilineal traditions in Minangnese society tend to facilitate intercultural communication between the Chinese and Minangnese in Padang (Alfirdaus, Hiariej \& Adeney-Risakotta, $2014,2016)$. Matrilineal customs emphasize the role of women in the family. The Minang constitute the world's largest matrilineal society (Navis, 2017). The formation of Minang culture is closely related to the matrilineal values contained in the feministic idea of "bundo kanduang" (biological mother), which, according to Alfirdaus, Hiariej, and Adeney-Risakotta (2014) has positively influenced the dynamics of the relationship between the Chinese and Minangnese in Padang. The matrilineal principle is characterized by a system of family ties through female members that are "motherly" in nature.

The principle of matrilineal affects the behavior patterns and social systems of the Minang community. After the age of eight, boys, if deemed sufficiently mature, no longer live in their mother's house, but in surau, a kind of boarding house. This custom, along with other factors, encourages Minang men to merantau, to leave their village to seek a livelihood elsewhere (Navis, 2017). On the contrary, the Chinese embrace a patrilineal family system, as evidenced by the use of the father's name as the name of the clan or tribe.

Despite having differing lineal customs, both the Chinese and the Minangnese are collective societies - oriented more toward the group than the individual. A defining characteristic of a collective society is a concern for relationships (Samovar, Porter \& McDaniel, 2010). Relationships in the Minang community are realized through customary law. A proto-democracy system, implemented since pre-Hindu times, determines important matters and legal issues according to customary law. The Minangkabau tribal principle is embodied in the statement "Adat basandi syarak, syarak basandi Kitabullah", tradition adheres to the law and the law to the Qur'an. This means that their traditions are based on Islamic teachings.

Apart from being bound by clan-based kinship, Chinese social relationships emerge from accumulated individual relationships (Fei Xiaotong, 1992). In Padang, there are two large Kongsi, ethnic-Chinese associations: Himpunan Bersatu Teguh (Unified Association/HBT) and Himpunan Tjinta Teman (Loving Friends Association/HTT). The presence of HBT and HTT has also helped to facilitate relationships between the Chinese and Minangnese communities. According to Erniwati (as cited in Fast/JPNN, 2011):

"These two associations (HBT and HTT) have become symbols of harmonious co-operation at the local level, while in the socio-economic level, it shows that ethnic Chinese and Minangnese can co-exist harmoniously" (Erniwati, Fast/JPNN, 2011).

\section{Religion}

There are also differences in the ethnic cultures of the Minangnese and the Chinese which are related to religion. The Minangkabau are, in general, devout Muslims, reflected the acknowledgement that their customs are based on Islamic teachings. On the other hand, the matrilineal basis of the Minang social system appears to be at odds with the teachings of Islam. Islam implicitly embraces the patrilineal system, as seen from the naming of children after their father. Prominent Minangnese poet Navis (2017) stated that the Minangkabau culture is more of an ethnic culture of a large and growing Malay clan due to its monarchy and/or matrilineal system, although the culture is strongly influenced by the teachings of 
Islam. In essence, Minangnese culture is a unique blend of the matrilineal social organization and Islam as a belief system. According to Elfira (2011), the matrilineal and Islamic principles are the deciding aspects which the Minangnese consider in managing relationships with other ethnic groups.

The Chinese religion is rooted in the teachings of ancient philosophers such as Confucius and Laozi. In Padang, although most Chinese profess Christianity, they still perform Confucian and Taoist rituals. The two Chinese ethnic associations: HBT and HTT, which are the only Chinese funeral providers in Padang, require that their members pray using hio, or incense. For the ethnic Chinese, the use of hio is part and parcel of their culture. Being a member of a society is essential for a Chinese person in Padang, both as their social identity and as a form of responsibility for maintaining the burial places of his parents, wife, and children. Thus, although different in terms of religion and family social system, the Chinese and Minangnese are groups with strong cultural traditions.

\section{Values}

The value system of both Chinese and the Minangnese draws on an ethos of commerce and exploration rooted in the principles of independence, hard work, and the desire to learn. In Minangkabau society, for example, young people are required to leave their village to study. Zubir (2009) found that for the Minangnese, young people are considered to be not useful in their village because they have no knowledge and wealth. Minangnese enjoy advantages similar to that of the Chinese in certain areas of trade. In theory, this could bring both groups into opposition and potential conflict (Erniwati, 2007). Apparently, however, this is not the case. The inter-ethnic relationship in Padang is devoid of conflict. Alfirdaus, Hiariej, and Adeney-Risakotta $(2014,2016)$ noted that the Minangkabau, like the Chinese, prefer cooperation or alliances over direct conflict.

Common interest reduces the potential for conflict in daily business interactions. Tanah Kongsi market, for example, is occupied by both Chinese and Minang traders. The Chinese traders consist mostly of people who sell pork, cookies, tofu, and traditional cuisines or who open grocery stores, coffee shops, and retail outlets. The Minangnese traders, who are in the majority, sell beef, fish, vegetables, fruits, and traditional cuisines. Some also open grocery stores. Traders often grant credit to customers temporarily unable to pay for purchases in full (Alfirdaus, 2014). In Tanah Kongsi market, Chinese and Minangnese seem to interact freely.

The economic cooperation between the Minangnese and Chinese is evident in the coffee stalls in Kampung Pondok area. Chinese shop owners, who generally sell only drinks and snacks, provide space for Minangnese to prepare and sell more substantial meals of typical Minang food such as sate and gado-gado in a mutually beneficial relationship. One coffee-shop owner (Informant Y) in the Simpang Kinol area, famous for evening snacks, even gives a "galon" (19 liters) of clean water to the food sellers on the shop terrace. "Elsewhere, the water is sold for Rp 2000 a galon," said Informant Y. As a sign of gratitude, the food sellers help sweep the shop yard after hours. At night, in a corner of Kampung Pondok, researchers also found another form of mutualistic relationship. The researchers noticed a Chinese woman on a bicycle who asked a Minang trader selling drinks whether she needed plastic bags for her merchandise. The Chinese woman turned out to be the supplier of plastic bags for the Minang trader. 
The mutualistic relationship between traders of the different ethnic groups in Simpang Kinol and elsewhere in Kampung Pondok has lasted for decades. Informant $Y$ has been co-existing with the same food sellers on the terrace of his house for about 30 years. When they retire, or for some reason cannot continue to operate, the food sellers pass on their business to a son or daughter. Such multi-generational relationships among merchants of differing ethnicities tend to develop into something akin to family ties. The researchers observed that when the ethnic Chinese celebrate Imlek, the lunar new year, their Minangnese fellow traders or suppliers would visit to wish them luck for the new year. In Padang, the relationships built on the basis of economic interests have, in some ways, grown into personal friendships which, in their turn, fosters a positive perception of both groups. Informant $\mathrm{Ri}$, a Minangnese who has interacted with numerous ethnic Chinese individuals as a friend, colleague, and employer, notes:

"I personally rate the Chinese ethnic group in Padang to be generally good, honest, tenacious, and hardworking individuals. Although some might not have the best intentions, I believe that is normal...negative traits exist in all ethnicities" (Informant Ri).

In addition, another informant (Un) stated that the Chinese in Padang are more mellow in behavior compared to the Chinese in Medan, the capital city of North Sumatra. Another Minangnese informant, (E) said:

"I hang out with a lot of Chinese people, and I think they are the same as us.

There is no difference because of the ethnicities, except in beliefs".

The Minangnese perception of their ethnic-Chinese neighbors tends to be positive. This perception seems to reflect the efforts of the Chinese population over the centuries to adapt to their social environment.

This study also found that both Chinese and Minangnese ethnic groups have relatively similar values in their approach to communicating. Both tend to be sensitive toward feedback or dynamics in communicating. A Chinese informant (Si) provides the following example:

"I was once coming out of a parking lot, and there was a parking attendant. At that time, he seemed annoyed. However, when I greeted him using the Minang language, he instantly became friendly" (Informant Si).

The use of the other's language (Minang) reduced the social distance between Informant $\mathrm{Si}$ and the attendant. The immediate response was, "Oh urang awak juo." which means, roughly: "Oh, you are from the same region as I am." However, Informant Si said that when a Minangnese makes an unpleasant facial expression while in conversation, the discussion should not be continued. Informant Si noted that the situational nature of the Minang community is considered to be important in maintaining a good relationship with a Minangnese. 
On the other hand, according to the Chairman of the West Sumatran National Unification Assembly (Informant A), the situational nature of the Minangnese can be explained by a Minang maxim: "Putiah kapeh bisa dicaliak, putiah hati bakaadaan." The maxim is loosely translated as "You can see the whiteness of the cotton, but the whiteness of the heart depends on the situation," meaning that the state of a person's heart depends on the circumstances, and this must be acknowledged. This situational philosophy is also applied by the Chinese, who are aware of their position as immigrants who must adapt to the local situation. "When talking to someone, we need to be sensitive to his or her responses," according to Informant $\mathrm{Si}$ in explaining the way he reads situations and socializes with Minangnese.

\section{Language}

The language used by the two ethnic groups is Minang. Although the Minang Pondok colloquial language used by the Chinese is heavily influenced by Mandarin (and the Hokkien dialect spoken by most historical migrants to Padang), it is fundamentally similar to standard Minang. Minang Pondok is used to communicate with non-Chinese and among the Chinese in general, between parents and children, and in the market. Occasionally, there may still be one-on-one conversations in Hokkien or Mandarin, such as when discussing financial matters, or referencing the Chinese calendar.

As the language of instruction in the daily life of the Chinese in Padang, Minang Pondok, according to Berger and Luckman (1991), regulates the lives of Chinese people in society. The flexibility of the Chinese to adapt to the majority group, through the adoption of the Minang language, gives them a common style of communication with the Minang ethnic group and allows both to communicate effectively in intercultural situations. One study also indicated a strong emphasis on the role of language in intercultural competence (Syarizan, Minah, Norhafezah \& Mohd Khairie, 2019).

The similarities and differences between the ethnic Chinese and Minangnese cultural elements are shown in Table 1 below:

Table 1: The Differences and Similarities of ethnic Chinese and Minangnese Cultural Elements

\begin{tabular}{lll}
\hline \multicolumn{1}{c}{ Cultural Elements } & \multicolumn{1}{c}{ Chinese } & \multicolumn{1}{c}{ Minangnese } \\
\hline History in Padang & Migrants from China & $\begin{array}{l}\text { Migrants from nearby } \\
\text { highlands }\end{array}$ \\
Social Organization & $\begin{array}{l}\text { Patrilineality } \\
\text { Collective Society } \\
\text { Religion }\end{array}$ & $\begin{array}{l}\text { Collective Society } \\
\text { Christian, Buddhist, }\end{array}$ \\
Calues & Confucian, & Muslim \\
& Trading Ethos & Trading Ethos \\
& Situational Nature & Situational Nature \\
& Flexibility to adapt & Flexibility to adapt \\
Language & Minang Pondok & Minang \\
\hline
\end{tabular}

Table 1 shows that more common characteristics of cultural elements exist between the two ethnic groups when compared to the differences. There are six common out of eight identified characteristics of cultural elements. These characteristics include collective society, trading ethos, ex-situ origins, a situational nature, flexibility to adapt and a common language. The differences are in religion and the social organization of the family, in which 
the Minangnese adhere to a matrilineal system, while the Chinese adhere to a patrilineal one.

Referring to the similarities of cultural elements, and the sensitivity of the two groups to communication situations, it can be inferred that communication between the Chinese and Minangnese in Padang tends to be interactional communication or a dialogical model. Some of the supporting factors are: first, awareness to the sensitivity of the perspective, message and feedback delivered by others, which is similar to role-taking. As exemplified by Informant Si and Informant A, when communicating they attempt to see the situation both from their and the other's point of view. As communication progresses, they observe the behavior of their interlocutors, then actively adjust. So, role taking is done actively and is oriented to all components of communication whether it is oneself, others, and, of course, the objects of the communication. Fisher (1986) says:

"In an interactional perspective, the communicator sees himself from the others' perspective and views others from his perspective. Therefore, the communicator can adjust his behavior with others by aligning his action with that of the others. The alignment of behavior or the existence of collective perception or collective action is, however, impossible without active role taking" (Fisher, 1986).

Second, attention is directed to verbal and non-verbal communication or the overall symbols. Informant $\mathrm{Si}$, for example, observed the parking attendant's expression before deciding to address him in Minang language. The third factor is adaptation by both parties. The principle of conformity has always been emphasized by all informants as a process which must be undertaken by the Chinese in Padang. The flexibility of the Minangnese, which is reflected in the "white cotton" adage, is also open to adaptation. One study of the Indonesian diaspora in Thailand also revealed that in order to build intercultural connection between Indonesian and Thai people in Thailand, Indonesians need to make cultural adjustments (Siagian \& Tike, 2019). This is similar to the situation of the Chinese in Padang. The consciousness of being minority immigrants influences the Chinese behavior to adapt to the locals. These adjustments, especially the adoption of the Minang language, support conducive inter-ethnic relationships. Finally, the other summarizing factors are the equality and overlapping or mutual interpretation of message exchanges between the Chinese and Minangnese (Fisher, 1986).

Interactional perspectives which are sensitive towards the dynamics of the situation in communicating are most likely to support harmonious inter-ethnic relationships in Padang, and are the ones which can also occur due to the similarity of some elements of culture for both ethnicities. Cultural similarity is also a component of isomorphism (Rakhmat, 2018). In this context, isomorphism refers to words or expressions having a common meaning in both cultures due to the similarity of past experiences or of cognitive structure. The similarity of meaning is more easily achieved where there are similarities in the socio-cultural background. As stated by Mulyana (2015), one of the principles of communication is: the more similar the socio-cultural background, the more effective communication will be. The similarity of meaning is important to communication, as it becomes an indication that communication takes place. The use of Minang Pondok helps 
the Chinese and Minangnese in Padang reach similarity of meaning in everyday communication.

On the other hand, the history of violence toward the ethnic-Chinese inhabitants of the archipelago created structural fear in the Chinese society in Padang. It affects Chinese perception of the external situation, especially related to safety and security. The stigma of the "rich Chinese" stereotype has also made them the "object of making money". In Tanah Kongsi, at least, this perception does not correspond with reality. Many ethnic-Chinese traders, such as sidewalk breakfast cakes and pastries merchants, gain their livelihood solely from commissions on direct sales. The cakes and pastries producers, also ethnic Chinese, fare little better, usually being widows or sole family providers making cakes and pastries by hand at home. The Minangnese also have a certain perception of Chinese people. Elfira (2011) found that in the Minangkabau community in Padang, there is an ethnic hierarchy in which other ethnic groups, including the Chinese, are seen as socially inferior to the Minangnese.

Nevertheless, from the results which indicate consciousness of both ethnic groups to honor their cultural achievement in maintaining relatively favorable inter-ethnic relations between the Chinese and Minangnese, their relationship is expected to remain harmonious. The efforts both sides make in an attempt to be sensitive to the situation is the hallmark of communication between the two ethnic groups. The sensitivity of the communicator to the dynamic of communication encourages a more precise response, which, in turn, results in more effective communication.

\section{CONCLUSION}

The smooth intercultural communication and relatively harmonious relations between the Chinese and Minangnese ethnic groups in Padang is a good model for other regions in Indonesia to support the further development of multiculturalism, a paradigm which promotes the social and political equality of the differing cultures in the society. The Padang model illustrates that positive inter-ethnic relationships are feasible when people are willing to look for and work on similarity in their cultural elements. In Padang, the Chinese and Minangnese ethnic-group preference for mutualistic relationships based on their trader ethos supports a long-term cooperation. This situation arose because the Chinese and Minangnese in Padang have similar cultural elements. Both have a societal history of economic migration leading to flexibility and adaptation to new environments, a collective principle of social organization, values that reflect sensitivity to the conditions of others and the environment, and a common tongue. Having more similarity than differences in cultural elements resulted in effective communication, and thus harmonious relationships between the Chinese and Minangnese ethnic groups in the city of Padang. Indeed, it is not an easy job maintaining inter-ethnic harmony between the Chinese and Minangnese in Padang. Hundreds of years of concerted, long-term effort by both groups, in particular the Chinese adaptation to the local environment, were required to reach and maintain the current state of positive inter-ethnic relations in Padang. 


\section{BIODATA}

Riniwaty Makmur is a doctoral graduate from Faculty of Communication Sciences, University of Padjadjaran in Bandung, Indonesia. She has worked as a corporate communication professional at PT. Chevron Pacific Indonesia, a subsidiary of Chevron Corporation, for 16,5 years, until April 2017. Currently, she is focusing in writing a book and teaching. Email: riniwaty15001@mail.unpad.ac.id

Engkus Kuswarno is a Professor and Head of Environment Communication Study Center at Faculty of Communication Sciences, University of Padjadjaran in Bandung, Indonesia. He is also a member of national team of lecturer certification, at Department of Higher Education, Ministry of Education and Culture. Email: kuswarno@unpad.ac.id

Evi Novianti is a senior lecturer and Head of Tourism Graduate Program Study, University of Padjadjaran in Bandung, Indonesia. Her research interest and area of specialization include public relations, communication strategy, and intercultural communication. Email: evi.novianti@unpad.ac.id

Nuryah Asri Sjafirah is a senior lecturer and Head of Journalism Department at Faculty of Communication Sciences, University of Padjadjaran in Bandung, Indonesia. Her research interest and area of specialization include communication research, journalism and media study, and intercultural communication. Email: nuryah.asri@unpad.ac.id 


\section{RUJUKAN}

Alfirdaus, L. K. (2014). Cultural practices and grass root democracy strengthening: A case study in two communities' collective recovery in indonesia's post-disaster situations. International Indonesia Forum, 2014 Working Paper Series 2. Retrieved from http://iif.or.id/wp-content/uploads/2015/01/02-Cultural-Practices-and-Grass-RootDemocracy-Strengthening_Reviewed.pdf

Alfirdaus, L. K., Hiariej, E., \& Adeney-Risakotta, F. (2014). Politik relasi etnik: Matrilinealitas dan etnik minoritas Cina di Padang, Sumatera Barat. Jurnal Komunitas, 6(1), 136-150. doi: 10.15294/komunitas.v6i1.294

Alfirdaus, L. K., Hiariej, E., \& Adeney-Risakotta, F. (2016). The position of Minang-Chinese relationship in the history of inter-ethnic groups relations in Padang, West Sumatra. Humaniora, 28(1). Retrieved from https://jurnal.ugm.ac.id/jurnalhumaniora/article/view/11506/8572

Berger, P., \& Luckmann, T. (1991). The social construction of reality - A treatise in the sociology of knowledge. UK: Penguin Books.

BPS (Statistical Bureau) Kota Padang. (2011). Pengolahan hasil sensus penduduk Kota Padang 2010.

Dahana, A. (2015). Indonesian peranakan Chinese: The origins and their culture. Retrieved from http://chinese.binus.ac.id/2015/02/18/indonesian-peranakan-chinese-theorigins-and-their-culture-by-prof-a-dahana/

Elfira, M. (2011). Inter-ethnic Relations in Padang of West Sumatra navigating between assimilation and exclusivity. Wacana, 13(2), 293-304. Retrieved from http://www.ijil.ui.ac.id/index.php/wacana/article/view/2550

Erniwati. (2007). Asap hio di Ranah Minang. Penerbit Ombak.

Erniwati. (2016). 140 tahun Heng Beng Tong sejarah perkumpulan Tionghoa 1876-2016. Komunitas Bambu. Retrieved from https://osf.io/ve7hw/

Fast/Jpnn. (7 December 2011). Cina Padang, berbahasa Minang logat Mandarin. Retrieved from http://www.jpnn.com/read/2011/12/07/110504/Cina-Padang,-BerbahasaMinang-Logat-Mandarin-

Fei, X. (1992). From the Soil. The foundation of Chinese society (A Translation of Fei Xiaotong's Xiangtu Zhongguo). US: University of California Press.

Fisher, B. A. (1986). Teori-teori komunikasi (Jalaluddin Rakhmat, Eds.). Bandung: Remadja Karya CV.

Griffin, E., Ledbetter, A., \& Sparks, G. (2019). A first look at communication theory. NY: McGrawHill Education.

Gudykunst, W. B., Lee, C. M., Nishida, T., \& Ogawa, N. (2005). Theorizing about intercultural communication. In W. B. Gudykunst (Eds), Theorizing about intercultural communication (pp. 3-32). Thousand Oaks: Sage Publications.

Hoon, C.-Y. (2006). Reconceptualising ethnic Chinese identity in post-Suharto Indonesia (PhD Thesis of the University of Western Australia School of Social and Cultural Studies Discipline of Asian Studies). Retrieved from https://scholar.google.com/scholar?hl=enandas_sdt=0\%2C5andq=chang+yau+hoon+ assimilation+universityandbtnG

Joyce Cheah Lynn-Sze, Norhafezah Yusof, \& Mohd Khairie Ahmad. (2014). The relevance of confucian values to leadership communication. Jurnal Komunikasi: Malaysian Journal of Communication, 30(Special Issue), 129-144. 
Kompas.com. (9 Mei 2017). Terbukti menodai agama Ahok Divonis 2 tahun penjara. Retrieved from https://megapolitan.kompas.com/read/2017/05/09/10560111/terbukti.menodai.ag ama.ahok.divonis.2.tahun.penjara

Liliweri, A. (2016). Konfigurasi dasar teori-teori komunikasi antarbudaya. Bandung: Penerbit Nusa Media.

Martin, J. N., \& Nakayama, T. K. (2010). Intercultural communication in contexts (5th ed.). NY: McGraw Hill.

Matamatapolitik.com (28 September 2018). Merpati putih atau kampanye hitam. Retrieved from https://www.matamatapolitik.com/pilpres-2019-merpati-putih-ataukampanye-hitam/

Moleong, L. J. (2015). Metodologi Penelitian Kualitatif. Bandung: PT Remaja Rosdakarya.

Mulyana, D. (2012). Cultures and communication: An Indonesian scholar's perspective. Bandung: PT Remaja Rosdakarya.

Mulyana, D. (2015). Ilmu komunikasi suatu pengantar. Bandung: PT Remaja Rosdakarya.

Navis, A. A. (2017). Pemikiran Minangkabau catatan budaya. Bandung: Penerbit Angkasa.

Qin, X. (2014). Exploring the impact of culture in five communicative elements case of intercultural misunderstandings between Chinese and American. Journal of Intercultural Communication, 34(March). Retrieved from http://immi.se/intercultural

Rakhmat, J. (2018). Psikologi komunikasi edisi revisi. Bandung: Simbiosa Rekatama Media.

Samovar, L. A., Porter, R. E., \& McDaniel, E. R. (2010). Komunikasi lintas budaya (Edisi 7, Translator: Indri Margaretha Sidabalok \& S.S. Salemba Humanika). Jakarta Selatan: Penerbit Salemba Humanika.

Samovar, L. A., Porter, R. E., \& Jain, N. C. (1981). Understanding intercultural communication. California: Wadsworth Publishing Company.

Setijadi, C. (2017). Chinese Indonesians in the eyes of the Pribumi public. Perspective ISEAS Yusof Ishak Institute, 73.

Siagian, H. F., \& Tike, A. (2019). Cultural adaptation of Indonesian diaspora in Thailand's social contexts. Jurnal Komunikasi: Malaysian Journal of Communication, 35(1), 268285.

Sugiyono. (2015). Memahami Penelitian Kualitatif. Penerbit Alfabeta, Bandung.

Suparlan. (2014). Menuju masyarakat Indonesia yang multikultural. Antropologi Indonesia, North America, 0. Retreived on 2019, October 23, from http://www.ijil.ui.ac.id/index.php/jai/article/view/3448/2729

Suryadinata, L. (2018, Jan 9). Ethnic groups and the Indonesian Nation-state from: Routledge handbook of contemporary Indonesia. US: Routledge. Retrieved on 2018, September 10, from https://www.routledgehandbooks.com/doi/10.4324/9781315628837-3

Syarizan Dalib, Minah Harun, Norhafezah Yusof, \& Mohd Khairie Ahmad. (2019). Exploring intercultural competence among students in Malaysian campuses. Jurnal Komunikasi: Malaysian Journal of Communication, 35(1), 1-16.

Zubir, Z. (2009). Silang bahasa dan budaya menuju integrasi bangsa. Linguistika Kultura, $3(1)$. 